\title{
Measurement of Evaporation from Salt Water Pan
}

\author{
by \\ Toshio Fujita and Nobuhiro Honda \\ Meteorological Research Institute, Japan
}

(Received August 14, 1979)

\begin{abstract}
Reliable measurements of evaporation are of importance in many scientific fields.

In the worldwide routine meteorological observation the evaporation rate per day is frequently measured by the evaporimeter pan.

The amount of evaporation can be roughly obtained by measuring water depth in the pan and this has been done by a hook gauge up to the present. In this method the wind often influences the measurement, and a small amount of evaporation for short periods of time could not be measured.

Recently, accuracy in measuring salinity was improved by use of an electric conductivity technique and it has become possible to measure salinity within an accuracy of $\pm 0.003 \%$. Then, even a trace amount of evaporation during a short time interval can be detected by measuring salinity change in the salt water pan.

The relative error is kept under about $2.5 \%$ by this method.

The sampling error of salinity was estimated not more than $4 \times 10^{-4} \%$ and the fallout of salt particles near the seashore was about $3.6 \times 10^{-5} \%$.

The amount of evaporation from two salt water pans of the same type showed a good agreement. Moreover, the difference between the amounts of evaporation from the salt water pan and the fresh water pan is not appreciable for long periods of time. However, the amount of evaporation from fresh water is apt to become larger as the observation time interval is shortened. It was found that the amount of evaporation from the salt water pan had a linear relationship to the vertical vapor fluxes estimated by the bulk method. The proportional coefficient of vapor fluxes to the amounts of evaporation from the pan was about 0.67 . It is a temporary value and should be determined from further experiments at various places and in various atmospheric conditions in future.
\end{abstract}

\section{Introduction}

Water is transported into the air as vapor through evaporation and water vapor plays an important role in the energy cycle in the atmosphere. Various weather phenomena also are closely related with the water cycle. Therefore the measurement of evaporation is of importance in meteorology.

It is pointed out that the amount of evaporation is one of the terms of water balance equation and is very necessary in- formation for planning, designing and operating reservoirs, irrigation and drainage.

From these points of view, the reliable measurements of evaporation are also needed in many scientific fields.

The amount of evaporation from an extensive area during a long time interval is often estimated by the methods of water or heat budget. On the other hand, the method of eddy correlation and the aerodynamic bulk method are suitable for measurement during a relatively short period of time when the atmospheric conditions are 
regarded as steady.

In the worldwide routine meteorological observation system, the evaporation rate per day is normally measured by the evaporimeter pan. However, this can not be regarded as natural evaporation except in atmospheric conditions soon after a heavy rainfall; it should rather be considered potential evaporation in the sense of evaporation from a limited water surface in a land area. Accordingly, it is desired that the amount of evaporation from the evaporimeter pan is transformed into the amount of vapor flux which expresses the average flux over some extent in the lower atmosphere.

A small amount of evaporation during a short time interval can be estimated by the eddy correlation method but such measurement becomes complicated. If an evaporimeter pan can be used in this case, there is nothing like this method.

However a trace amount of evaporation can hardly be estimated by the usual method of evaporimeter pan. Since evaporation is estimated from the decrease of water depth during a time interval and the water depth is measured by a hook gauge, the wind often influences the measurement. Accordingly the evaporation during short periods of time can not be determined exactly by this method. Moreover, the evaporimeter pan is not free from the effects of birds and animals drinking the water. In order to eliminate these difficulties and to make it possible to estimate evaporation by the evaporimeter pan during a short time interval (for example, for 30-min. or an hour), we tried to estimate evaporation from the change of salinity of salt water in the pan.

\section{Problems in the measurement of evaporation from salt water}

T. C. Adams (1934) made several experiments with the evaporimeter pan which contained water from the Great Salt Lake. He showed that the amount of evaporation decreases by about one per cent for each one per cent increase in the specific gravity of the salt water. However, the salt content of the Great Salt Lake is very dense, that is, about $250 \%$, which was ten times as large as our salt water. Accordingly his conclusion mentioned above can not be directly compared with our experiments in which salt water of little concentration (about $25 \sim 30 \%$ ) was used. In fact, our comparative measurement of evaporation from fresh water and from salt water indicated that the evaporation amount from the latter was rather $0.03 \mathrm{~mm}$ more than that from the former in the daytime $(10 \sim$ $17 \mathrm{~h})$ but $0.14 \mathrm{~mm}$ less at night $(17 \sim 10 \mathrm{~h}$, the next day). Fig. 1 shows a comparison of evaporation from fresh water with that from salt water.

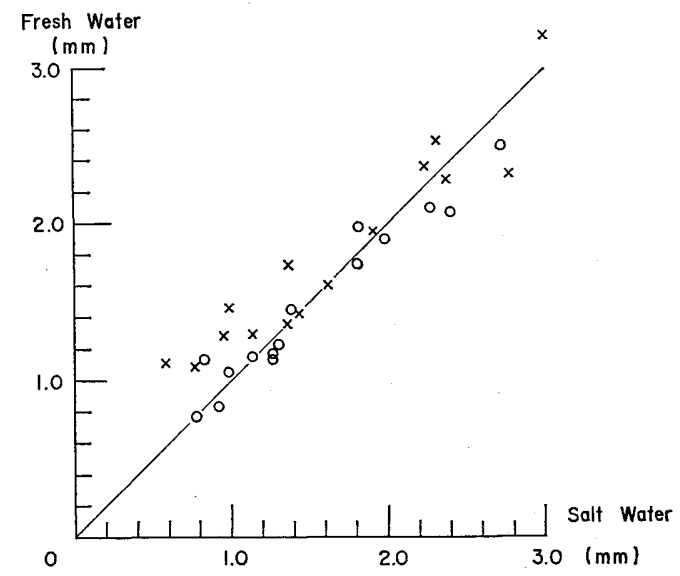

Fig. 1. Comparison of evaporation between from fresh water pan and from salt water pan. $\bigcirc$, indicates the daytime evaporation $(10 \mathrm{~h} \sim 17 \mathrm{~h}) \times$, the night-time one $(17 \mathrm{~h} \sim 10 \mathrm{~h}$, the next day)

In these experiments we used two circular evaporimeter pans $(50 \mathrm{~cm}$ in diameter and $60 \mathrm{~cm}$ deep) and these were sunken in the lawn ground, whose rims were about $10 \mathrm{~cm}$ above ground level. Both pans were made of iron and painted white.

In Japan, H. Kawasaki (1934) carried out the earliest measurements of evaporation from salt water in the pan. In 1933, he installed two small evaporimeter pans 
on board a research vessel, Shumpu-Maru.

These pans were made of copper and $20 \mathrm{~cm}$ in diameter, $10 \mathrm{~cm}$ deep. Their bases were painted silver in color to minimize the influence of insolation. Salt and fresh water were respectively put in each pan. He reported that the amounts of evoporation from the two pans fell within the range of $\pm 10 \%$ of the mean value. He applied the silver nitrate titration technique to measure the salinity of salt water.

According to the Manual of Oceanographic Observation, J. M. A. (1970), a solution of silver nitrate is in this technique, added drop by drop to the sample of salt water. Then $\mathrm{Ag}^{+}$in the solution of silver nitrate combines with $\mathrm{Cl}^{-}$in the salt water and insoluble white sediments of silver chloride $(\mathrm{Agcl})$ result.

By use of potassium chromate $\left(\mathrm{K}_{2} \mathrm{CrO}_{4}\right)$ as an indicator beforehand, the chemical process after the terminal point of titration is formularized as follows:

$$
\mathrm{CrO}_{4}^{2-}+2 \mathrm{Ag}^{+}=\mathrm{Ag}_{2} \mathrm{CrO}_{4} \text {. }
$$

As a result of this reaction, the terminal point of titration can be determined when silver chromate $\left(\mathrm{Ag}_{2} \mathrm{CrO}_{4}\right)$ shows a red-brown color.

However, this technique has the following defects :

(1) Chrorine ions $\left(\mathrm{Cl}^{-}\right)$are apt to be absorbed by the sediments of silver chloride.

(2) In the case of small salt contents it is difficult to determine the terminal point of titration, since the color of the solution slowly changes.

Consequently, it is said that the accuracy of measuring salinity by this technique is about $\pm 0.02 \%$.

On the other hand, the salinity in salt water has recently been determined by measuring its electric conductivity. This technique, which is now wide spread, is very simple and has very high measuring accuracy, i. e. only $\pm 0.003 \%$.

Thus, as accuracy of measurement has been raised by one order, even a small amount of evaporation for a short period of time has been made detectable with the change of salinity in the salt water pan.

In the measurement of salinity of the sample of salt water, we used the inductive coupled salinometer manufactured by AutoLab Industries PTY. LTD.

\section{Principles of measurement of evapora- tion from the salt water pan and the estimation of errors due to various causes}

We take up a column of salt water occupying a unit area in the evaporimeter pan and denote the depth of the column by $h \mathrm{~cm}$ and its salinity by $S \%$.

If, after several hours, the salinity $S \%$ has changed to $S^{\prime} \%$ and $e \mathrm{~cm}^{3}$ of water has evaporated during that time interval, the following equation can be derived.

$$
h S=(h-e) S^{\prime}
$$

Therefore, the amount of evaporation is expressed by

$$
e=h \cdot \Delta S / S^{\prime}
$$

where the increment $\Delta S$ means the change of salinity $\left(S^{\prime}-S\right)$ and $h$ is the water depth.

The measuring error of evaporation originating from the measurement of $h$ and $S$ may be estimated as follows:

$$
\begin{gathered}
\delta e=\delta h \cdot \frac{\Delta S}{S^{\prime}}+h \cdot \delta\left(\frac{\Delta S}{S^{\prime}}\right) \\
\fallingdotseq \delta h \cdot \frac{\Delta S}{S^{\prime}}+h \cdot \frac{\delta(\Delta S)}{S^{\prime}}
\end{gathered}
$$

If $S$ and $S^{\prime}$ were measured independently, the standard deviation of $\Delta S$ would be equal to $\sqrt{2} \sigma_{s}$. $\sigma_{s}$ means the standard deviation of $S$.

When the numerical values, $0.35 \%$, $0.0042 \%, 100 \mathrm{~mm}, 1 \mathrm{~mm}$ and $35 \%$ are assigned to the variables, $\Delta S, \delta(\Delta S), h, \delta h$ and $S^{\prime}$ respectively, the measuring error of evaporation $\delta e$ will be equal to $0.022 \mathrm{~mm}$.

In this case, the amount of evaporation is $1 \mathrm{~mm}$ from eq. (2), since the relative error $(=\delta e / e)$ is equal to only $2.2 \%$. 
Next, the effect on evaporation of the saturated vapor pressure at the surface of salt water should be examined.

The saturated vapor pressure at the surface of salt water is expressed by the following formula.

$$
f_{s}=f_{d}(1-0.00053 S),
$$

where $f_{s}$ is the saturated vapor pressure at the surface of salt water with the salinity $S \%, f_{d}$, the same at the distilled water surface. If $S$ is equal to $35 \%, f_{s}=0.98 f_{d}$. The difference between the two quantities is about only $2 \%$.

The amount of evaporation was observed with the use of a white plastic pan $(100 \mathrm{~cm}$ in diameter and $15 \mathrm{~cm}$ deep) and the water depth was always kept at about $10 \mathrm{~cm}$ by supplying salt water at times.

In order to measure the salinity of salt water, about $100 \mathrm{cc}$ of water was sampled in a small bottle, after stirring the water in the pan for very short time so that the salinity of the water might become homogeneous and the influence of evaporation be extended to the bottom of the pan.

Whenever salt water was sampled, the depth of water was also read by a hook gauge. It was sufficient to measure $h$ with accuracy of $\pm 1 \mathrm{~mm}$. As seen from eq. (3), if the error of measuring $h$ is within \pm 1 $\mathrm{mm}$, the error of evaporation due to this accuracy will be $\Delta S / S^{\prime}(\mathrm{mm})$.

The root mean square of the salinities of two bottles simultaneously sampled was below $4 \times 10^{-4} \%$ and the fallout of saltparticles sampled at a distance of $300 \mathrm{~m}$ from the seashore was only $3.6 \times 10^{-5} \%$. These values are out of the question as error sources because they are within the range of accuracy of measurement.

\section{Comparison of evaporation from the salt water pan with the other estima- tions of evaporation}

A comparison of the two amounts of evaporation from two salt water pans for various time intervals is shown in Fig. 2. The root mean square of the two amounts is equal to only $0.02 \mathrm{~mm}$.

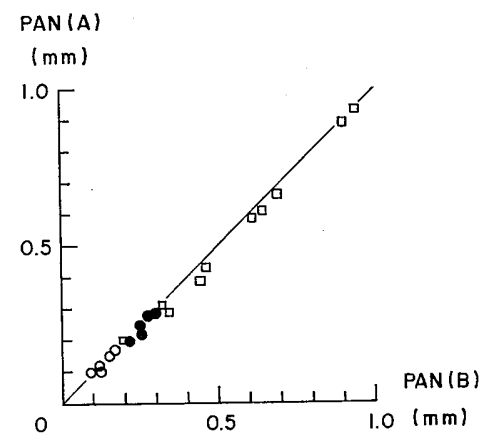

Fig. 2. Sampling error of amount of evaporation durng a relatively short period from two salt water pans. $O$, indicates the evaporation for $30 \mathrm{~min}$. the same for an hour. $\square$, the same for 4 hours.

Fig. 3 shows comparisons between the amounts of evaporation from the salt water pan and those from the fresh water pan. Amounts of evaporation for a long time interval agree well with each other, but the measuring errors of the depth of fresh water tend to become larger as the time interval is shortened.

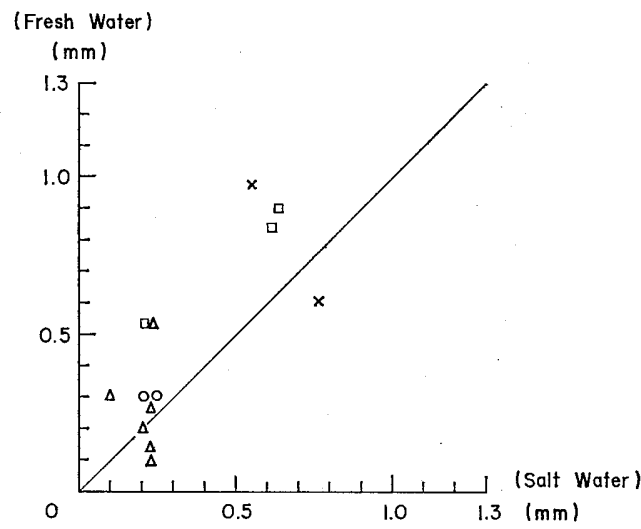

Fig. 3. Comparison of measurement of evaporation during a relatively short period between from fresh water pan and from salt water pan. $\bigcirc$, indicates the evaporation for an hour. $\triangle$, the same for 2 hours. $\square$, the same for 4 hours. $x$, the same for 8 hours. 
This is because it is difficult to measure a small difference of depth even by a hook gauge. Consequently, it is desired that the amount of evaporation for time intervals less than $12 \mathrm{hrs}$. should be measured by the present method.

Finally, the amounts of evaporation from the salt water pan were compared with the estimates of vapor fluxes obtained from the bulk method which was developed by T. Fujita (1978). The linear relationship between evaporation from the pan and the turbulent vapor fluxes is shown in Fig. 4.

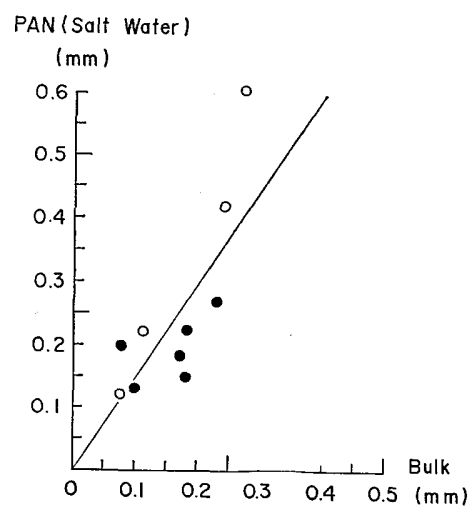

Fig. 4. Linear relationship between the evaporation from the salt water pan and those obtained from the iterative bulk method. $\bigcirc$, indicates values at Chiba experiment (1967). values at Kasumigaura experiment (1970).

The thirty-minute averages of wind speed and the dry and wet bulb temperature of the air were observed at the heights of $0.5 \mathrm{~m}$ and $2 \mathrm{~m}$ near the evaporimeter pan. These observations were made on the open reclaimed ground of Chiba port in the autumn of 1967 and on the shore of the lake of Kasumigaura in the autumn of 1970. The stratifications of the atmosphere were from unstable to near neutral. The vapor fluxes were estimated by applying these data to the bulk method mentioned above.

The ratio of vapor fluxes to the amount of evaporation from the pan was about 0.67 .

According to I. Oshida (1948), it seems that the evaporation from an extensive lake surface is about two thirds of that from a pan and the yearly amount of evaporation from bare land is about half to two thirds of that from a water surface which has the same area as the land. Accordingly the value of this ratio, 0.67 , is not be so doubtful, but as this agreement may be accidental, it should be determined from further experiments in various places and atmospheric stratifications in future.

\section{Summary and conclusions}

(1) Recently, the development of the measuring technique by use of electirc conductivity has made it possible to detect a small amount of salinity change with an accuracy of $\pm 0.003 \%$, and consequently a small amount of evaporation has become measurable.

(2) If the change of salinity, $\Delta S$, was $0.35 \%$, the terminal salinity $35 \%$ and the depth of water measured $100 \mathrm{~mm}$ with an accuracy of $1 \mathrm{~mm}$, the amount of evaporation and its error will be estimated at $1 \mathrm{~mm}$ $\pm 0.022 \mathrm{~mm}$.

(3) Sampling error from the salt water pan was less than $4 \times 10^{-4} \%$ and the fallout of salt-particles near the seashore was only $3.6 \times 10^{-5} \%$. These values are out of the question as error sources.

(4) The amounts of evaporation from two salt water pans for various time intervals showed a good agreement.

(5) For a long time interval, the amounts of evaporation from the salt water pan and those from the fresh water pan are approximately equal with each other. But the measuring errors of the depth of fresh water tend to become larger as the observational time interval is shortened.

(6) Finally, the amounts of evaporation from the salt water pan were compared with the estimates of vapor fluxes obtained from the bulk method. The ratio of vapor fluxes to the amounts of evaporation from the pan was about 0.67 . This ratio is a temporary value and should be determined from furthere experiments at various places 
and in various thermal conditions of the atmosphere in future.

Acknowledgements:- The authors wish to express their hearty thanks to Dr. Eiji Uchida, Meteorological Research Institute, for his reading of the manuscript and valuable advice and comments. They also thank their colleagues including $\mathrm{Mr}$. M. Tosha (M. R. I.) for their co-operation in the field observations.

They are also indebted to Mr. Y. Katsuragi of the Geochemical Division, M. R. I., for his kind help in measuring salinity.

\section{References}

Adams, T.C., 1934: Evaporation from great salt lake. Bull. Amer. Met. Soc. 15, 35-39.

Fujita, T., 1978: Determination of turbulent flux by the bulk method using measurements at two levels. Pap. Met. Geophys. 29, 1-15.

Japan Meteorological Agency, 1970: Manual for Oceanographic Observations (in Japanese).

Kawasaki, H., 1934: Evaporation from sea water (1st report), UMI to SORA $14,357-365$ (in Japanese).

Oshida, I., 1948: Evaporation and drying. P. 135 Kawade Shobō (in Japanese).

\section{塩水蒸発計からの蒸発量の測定}

\section{藤田敏夫・本多庸浩}

信頼できる蒸発量の測定は気象をはじめ，多くの科学分野で重要である。世界の気象観測業務では一日間の蒸発 量をクラス Aパンなどの大型蒸発計を使って測定しているところが多い。この場合, 蒸発量は皿の中の水深をフッ クゲージで測定して求めている。そのため, 風が測定に影響を及ぼすし, とくに短時間の少ない蒸発量はこの方法 では求めることは出来ない。

最近, 塩分測定技術が電気伝導度法を用いることによって改良され，0.003\%のの精度で塩分濃度を測定できるよ らになった。そこで電気伝導度法を用いた塩分測定技術を応用して短時間の蒸発量でも正確に測定し得る方法をこ

〉で提案する。この方法の検討結果は以下の通りである。

この方法による蒸発量測定の相対誤差は約 $2.5 \%$ 以下にすことができる。標本抽出誤差は $4 \times 10^{-4} \%$ 以下で あり，海盐粒子などの降下量は海岸から $300 \mathrm{~m}$ 位はなれた所で測定して $3.6 \times 10^{-5} \%$ 位の值に過ぎなかった。

同じ型の二つの塩水蒸発計からの蒸発量はよい一致を示し, 平均自乘誤差は $0.02 \mathrm{~mm}$ に過ぎない。また, 淡水 蒸発計々塩水蒸発計からの蒸発量は観測時間が長いときはよく一致するが，時間々隔が短かくなるにつれて淡水蒸 発計からの蒸発量が多くなる傾向がみられた。この原因の一つは淡水蒸発計の水深測定の愦差によるものと考兄ら れる。

塩水蒸発計からの蒸発量はバルク法で求めた水蒸気の鉛直輸送量と直線関俰が認められた。後者の前者に対する 比は約 $2 / 3$ であった。この值は二カ所の野外実験で得られたるので, 将来いろいろな場所で色々な大気安定度に対 して実験を重ねる必要があうう。 